\title{
SEDEM LET ČLANSTVA V NATU - ALTERNATIVE PRED VSTOPOM IN UČINKI DANES
}

\section{SEVEN YEARS OF NATO MEMBERSHIP - ALTERNATIVES BEFORE THE ACCESSION AND ITS EFFECTS TODAY}

Polemic, discussion

Povzetek S članstvom v Natu je Slovenija dosegla enega svojih ključnih političnih ciljev. Pot v zavezništvo je trajala deset let, temeljila je na argumentih, ki so podpirali odločenost, na izpolnjevanju zavez, kar nam je zagotavljalo kredibilnost, in na podpori javnosti. Po sedmih letih članstva je čas za oceno njegovih učinkov, pa tudi priložnost za pogled nazaj na možnosti, ki so nam bile pred dokončno odločitvijo na referendumu na voljo.

Ključne

Nato, alternative, učinki članstva.

besede

Abstract By becoming a NATO member, Slovenia has implemented one of its key political goals. The road to NATO, however, took ten years and was based on the arguments, which supported our determination, on the fulfilment of commitments that provided us with credibility, and on the public support. After seven years of membership the time has come to asses the effects of the membership as well as to look back at the options which had been available before taking the final decision in the referendum in March 2003.

Key words NATO, alternatives, effects of membership.

\section{Uvod Pot v Nato kot jasen politični in strokovni cilj}

Sedem let članstva v Natu je več kot tretjina obstoja Slovenije kot samostojne in neodvisne države. Odločitev za članstvo in proces vključevanja pa obsegata skoraj večino obdobja samostojne Slovenije. Tako so bili že v februarskem (1994popravku Resolucije o izhodiščih zasnove nacionalne varnosti, ki jo je konec decembra 1993 sprejel Državni zbor, formalizirani približevanje Natu in odnosi z zavezništvom. Kmalu zatem je tedanji predsednik slovenske vlade podpisal dokument o 
formalnem pristopu Republike Slovenije k Natovemu programu Partnerstvo za mir. Leto pozneje je Slovenija opravila prvo usklajevanje v tako imenovanem Natovem programu za doseganje povezljivosti oziroma programu PARP, povezanem z uvedbo nacionalnih zmogljivosti za sodelovanje pri skupnem usposabljanju in delovanju $\mathrm{V}$ okviru Partnerstva za mir. Skoraj hkrati je bil sprejet tudi prvi individualni partnerski program sodelovanja med Natom in Republiko Slovenijo, s poudarkom na prilagajanju obrambnega sistema in vojaške strukture, izobraževanju, vajah, standardizaciji ter doseganju drugih izhodišč iz okvirnega dokumenta Partnerstva za mir na civilnem in vojaškem področju.

Septembra 1995 je zavezništvo partnericam predstavilo študijo o širjenju Nata, s katero sta se slovenska politika in stroka na področju nacionalne varnosti seznanili oktobra. Naslednji mesec je Severnoatlantski svet sprejel sklep o začetku individualnega dialoga s kandidatkami za članstvo v Natu, za katerega je interes pokazala tudi Slovenija. Štirje krogi individualnega dialoga med Slovenijo in Natom so potekali med aprilom 1996 in aprilom 1997. V tem dialogu je Slovenija predstavila svoje poglede na širitev Nata ter pomen procesa za celotno evropsko varnost, politično in gospodarsko ureditev države, svojo varnostno in obrambno organiziranost ter prihodnje dejavnosti za članstvo v zavezništvu.

V tem obdobju so bile sprejete tudi pomembne politične odločitve in zaveze $\mathrm{V}$ Sloveniji. Tako je aprila 1996 Državni zbor sprejel sklep, da želi RS zagotoviti svoj temeljni varnostni interes $\mathrm{v}$ okviru sistema kolektivne obrambe, ki ga omogoča članstvo v Natu, aprila naslednjega leta pa je sprejel deklaracijo o vključevanju v Nato, ki opredeljuje, da Slovenija izpolnjuje vse pogoje za vključitev ter da je sposobna in pripravljena kriti svoj del stroškov polnopravnega članstva v zvezi.

Celotnemu dotedanjemu procesu je sledilo razočaranje na vrhu Nata v Madridu julija 1997, ko je bilo vabilo za članstvo posredovano le trem državam, med katerimi ni bilo Slovenije. Analiza razlogov za neuspeh v Madridu je omogočila pripravo ključnega strateškega dokumenta, to je Nacionalne strategije Republike Slovenije za vstop v Nato, ki je bila sprejeta februarja 1998.

V strategiji so bili prvič celovito navedeni razlogi za vključevanje Slovenije v zvezo. Izhodišče za članstvo so bile vrednote slovenske države, ki so temelj njenega razvoja ter hkrati določajo njen položaj v mednarodni skupnosti, to so mir in varnost državljanov, ozemeljska celovitost in suverenost države, pravna in demokratična ureditev države, varstvo človekovih pravic in manjšin ter blaginja posameznika in družbe. Izhajajoč iz teh temeljnih vrednot in dolgoročnih interesov je bilo kot eden izmed glavnih ciljev zunanje in tudi nacionalnovarnostne politike Republike Slovenije določeno tudi polnopravno članstvo v Natu, saj naj bi bil v takratni evropski varnostni arhitekturi Nato edina operativno sposobna organizacija kolektivne obrambe. Članstvo v Natu bi okrepilo varnost Republike Slovenije, prispevalo k njenemu dolgoročnemu razvoju ter imelo tudi pomembne in obsežne posledice na zunanjepolitičnem, varnostnem, vojaškem, gospodarskem, znanstvenem, raziskovalnem in 
tehničnem ter drugih področjih. Poleg tega bi članstvo v Natu pomenilo umestitev Republike Slovenije v politični in varnostni okvir najrazvitejših zahodnoevropskih držav in držav Severne Amerike, omogočilo bi pospeševanje družbenega in gospodarskega razvoja ter sodelovanja Slovenije z državami članicami Nata, okrepilo bi ugled, mednarodni položaj in pogajalsko moč ter utrdilo varnostni in mednarodnopravni položaj Slovenije v Evropi in svetu. Utrdilo bi tudi mednarodno identiteto Slovenije kot demokratične, miroljubne in v povezovalne procese usmerjene države. (Nacionalna strategija, 1998)

V strategiji so bile opredeljene tudi posledice članstva, kot jih je bilo takrat mogoče določiti. Tako naj bi bile najpomembnejše neposredne koristi članstva v Natu:

- zagotovitev dolgoročnega stabilnega mednarodnega politično-varnostnega okolja, ki bo spodbujalo vsestranski družbeni razvoj;

- večja stopnja nacionalne varnosti;

- soodgovornost in soodločanje o varnostnih vprašanjih in izzivih v Evropi kot tudi soodgovornost in soodločanje za reševanje težav na kriznih območjih v Evropi;

- krepitev ugleda in pogajalske moči Slovenije;

- utrditev statusa Slovenije kot države z nizko stopnjo poslovnega tveganja in rizičnega vlaganja.

Ob tem so bile navedene tudi posredne koristi, ki naj bi obsegale predvsem:

- vključenost v znanstvene, tehnološke in informacijske tokove najrazvitejših držav;

- gospodarsko sodelovanje z najrazvitejšimi državami, tudi na vojaškem področju;

- dolgoročno znižanje izdatkov za obrambo in pocenitev oziroma okrepitev konkurenčne sposobnosti slovenske vojaške industrije.

Bilo je preveč optimistično pričakovati, da bo Slovenija res dobila vabilo na vrhu v Washingtonu. Rezultat tega vrha je bil, da so zaupanja vredne kandidatke dobile možnost sodelovanja v akcijskem načrtu za članstvo. Slovenija se je vanj vključila oktobra 1999 s prvim letnim načrtom in ga zaključila oktobra 2003 s predajo petega letnega načrta. Akcijski načrt za članstvo je temeljil na oblikovanju programa dejavnosti, ki bi kandidatkam pri pripravah na članstvo pomagale v političnih, gospodarskih, obrambnih, vojaških, varnostnih in pravnih zadevah. Ključno je bilo, da je bila država pripravljen a na delitev vlog, tveganj, odgovornosti, ugodnosti in bremen skupne varnosti ter kolektivne obrambe, prevzem strategije zavezništva, zagotavljanje sil in zmogljivosti ter pripravljena nameniti zadostna proračunska sredstva za uresničevanje svojih obveznosti.

Junija 2001 je Državni zbor sprejel novo Resolucijo o strategiji nacionalne varnosti, s katero je potrdil temeljno usmeritev za slovensko članstvo v Natu, saj je med temeljnimi vrednotami, ki jih zagotavlja zunanja politika Republike Slovenije, tudi varen položaj v mednarodni skupnosti, ki ga namerava Slovenija zagotavljati s članstvom v Natu. Uresničevanje tega nacionalnega interesa zahteva, da se Slovenija z akcijskim načrtom za članstvo in partnerstvo za mir aktivno in vsestransko pripravlja na prevzem zavezniških nalog. Z graditvijo svojih oboroženih sil ter ustreznimi 
zunanjepolitičnimi odločitvami si Republika Slovenija utrjuje položaj prihodnje članice Nata. Še posebno pomembni sta aktivna vloga Republike Slovenije in njeno sodelovanje z Natom pri prizadevanjih za odpravo kriznih žarišč v Jugovzhodni Evropi. Kar je pomembno tudi za sedanje razmišljanje o nacionalnem konceptu obrambe, je določilo, da bo obrambni sistem v sistemu kolektivne obrambe uresničeval naloge, ki jih bo Republika Slovenija prevzela z vključitvijo v Nato (Resolucija o strategiji nacionalne varnosti, 2001).

Novembra 2002 je bila Slovenija na vrhunskem zasedanju Nata v Pragi povabljena, naj začne pristopne pogovore za članstvo v zavezništvu. Pogovori so potekali v dveh krogih, januarja 2003. Dva meseca pozneje, 23. marca, je na referendumu 66,08 odstotka volivcev podprlo odločitev o članstvu v zavezništvu.

Z naslednjim korakom marca 2002 so bili na podlagi pisma in časovnice reform postavljeni temelji našega članstva v zvezi. Časovnica je poleg drugih vsebin vključevala tudi zaveze države, da bo pripravila ustrezno zakonodajo za sodelovanje $\mathrm{v}$ kolektivni obrambi, vključno z odločanjem slovenske vlade o napotitvi poklicnih pripadnikov in prostovoljnih rezervistov $\mathrm{v}$ tujino, o odpravi obvezniške vojske do konca 2004 in obvezne rezerve do konca 2010, o zmanjšanju vojne strukture Slovenske vojske na 14.000 (od tega vsaj 8000 poklicnih) pripadnikov. Slovenska vlada se je zavezala tudi, da bo do konca leta 2010 oblikovala premestljivo bataljonsko bojno skupino z rotacijo do konca leta 2012 in da bo ohranjala takšno raven obrambnih izdatkov, ki bo zagotavljala izvajanje obrambnih reform, prestrukturiranje in modernizacijo slovenske vojske ter krepitev povezljivosti in bojne učinkovitosti, zmožnost premestitve ter vzdržljivost njenih enot, kar pomeni tudi povečanje obrambnih izdatkov na dva odstotka BDP do leta 2008, v nadaljevanju pa tudi ohranjanje te višine (Časovnica, 2003).

Devetindvajstega marca 2004 je Republika Slovenija postala polnopravna članica Nata.

\section{ALTERNATIVE LETA 2003}

Ali je Slovenija imela alternativo članstvu v Natu? Od vključitve v Parterstvo za mir je svoje politično, varnostno, obrambno in v manjšem delu tudi ekonomsko ter pravno delovanje usmerila v članstvo v zavezništvu. Po desetih letih od pristopa k parterstvu nam je ta cilj uspel. Ves obrambni sistem s Slovensko vojsko se je vsaj od leta 1998, po sprejetju Akcijskega načrta za članstvo, prilagajal prihodnjemu članstvu v zavezništvu. Čeprav smo z vsemi aktivnostmi uspeli zagotoviti status zaupanja vredne kandidatke in tako tudi vabilo v članstvo, pa je bilo ključno vprašanje uspešnost referenduma. Kljub intenzivni kampanji ter predstavitvi argumentov za in proti članstvu so dogodki v Iraku, ki so se začeli neposredno pred referendumom, povzročili nekaj nelagodja pri predlagateljih in zagovornikih. 
Slovenska obramboslovna stroka je pripravila svoje poglede in presojo drugih možnosti, kot so: Slovenija kot razorožena in nepovezana država, razorožena država pod dvostransko varnostno zaščito, država z obrambno samooskrbo brez varnostne povezave ali posnemanje avstrijskega modela oziroma trajna obrambna povezava $\mathrm{z}$ neko drugo državo ali državami (Bebler, 2002).

Malo znano je bilo, da je bila za vlado na Ministrstvu za obrambo marca 2003 pripravljena analiza posledic, če članstvo v zavezništvu ne bi dobilo podpore. Vsebina dokumenta je temeljila na oceni tveganj, posledic in možnosti za zagotavljanje nacionalne obrambe, če se Slovenija ne bi včlanila v Nato.

Analiza je izpostavila politična tveganja in negotovosti, ki bi jih povzročilo nečlanstvo Slovenije v Natu:

a) Nečlanstvo v Natu bi pomenilo zanikanje desetletne zunanjepolitične in nacionalnovarnostne strategije. Zaradi tako očitne in globoke politične diskontinuitete bi bili na teh področjih prisiljeni delovati v bistveno spremenjenih okoliščinah, ki bi jih lahko označili kot zunanjepolitični in nacionalnovarnostni bankrot RS.

b) Z zavrnitvijo članstva $v$ Natu bi RS postala politično prepoznavna država, seveda z negativnim predznakom, $\mathrm{v}$ mednarodni skupnosti bi izgubila velik del svoje politične verodostojnosti in potrdila sorazmerno močne predsodke o domnevni samovšečnosti, sebičnosti in ošabnosti.

c) Referendumski rezultat, ki bi nasprotoval članstvu Slovenije v sistemu kolektivne obrambe, bi bil glavni pokazatelj neodločnosti in omahovanja pri prevzemanju aktivnejšega in odgovornejšega položaja Slovenije v evroatlantski skupnosti. S tem bi država izgubila možnost neposrednejšega in vidnejšega vpliva na politično-varnostna in predvsem vojaškoobrambna vprašanja v ožjem mednarodnem (JV-Evropa) in širšem evroatlantskem prostoru (če na primer Belgija ne bi bila članica Nata, ji pri nasprotovanju vojni v Iraku nihče ne bi namenjal tolikšne pozornosti).

d) Ni povsem jasno, ali bi zavrnitev članstva $\mathrm{v}$ Natu pomenila kakšno posebno tveganje in negotovost za članstvo v Evropski uniji, vendar je gotovo vsaj to, da bi bili brez članstva v Natu pri kakršnih koli prihodnjih pogajanjih o statusu RS v EU v bistveno slabšem pogajalskem položaju kot sicer.

e) Zunaj Nata bi bila Slovenija v prihodnje verjetno bolj izpostavljena morebitnim političnim in drugim pritiskom sosednjih in bližnjih držav, ki bi skušale svoje nacionalne interese uveljavljati na njen račun. Sosednje države bi lahko zavrnitev povabila za članstvo v Natu razumele tudi kot znamenje politične šibkosti.

f) Zavrnitev članstva $v$ Natu bi bila brez dvoma zelo slab signal za stabilizacijske procese v JV-Evropi. V tem primeru bi Slovenija zelo verjetno morala prevzeti vlogo krivca, ne le za morebitni zastoj ali celo konec nadaljnje širitve Nata na JV (koncept odprtih vrat), temveč bi lahko bila z vidika mednarodne skupnosti vsaj posredno odgovorna tudi za kakršne koli zastoje ali težave v procesu krepitve miru in varnosti v JV-Evropi. Brez dvoma pa bi z zavrnitvijo članstva v Natu izgubila status najbolj verodostojnega in konstruktivnega parnerja pri umirjanju razmer v tem delu Evrope. 
Ugotovitve, povezane z varnostnimi tveganji in negotovostmi:

a) Dolgoročnih sprememb v politično-varnostnem okolju ni mogoče povsem jasno predvideti in opredeliti. Če se Slovenija ne bi vključila v sistem kolektivne obrambe, bi to pomenilo predvsem dolgoročno (ob neugodnem spletu različnih okoliščin lahko že tudi srednjeročno) tveganje in negotovost vplivanja kakršnih koli politično-varnostnih sprememb v ožjem mednarodnem (JV-Evropa) in širšem strateškem okolju RS. Pri tem je treba upoštevati okoliščine, izhajajoče iz slovenske zgodovine, geostrateškega položaja, geografske, gospodarske in demografske majhnosti ter s tem povezane sorazmerno velike občutljivosti na morebitne vplive politično-varnostnih sprememb, čeprav morda po obsegu in intenzivnosti omejenih.

b) Ob strateškem poslabšanju politično-varnostnega položaja v ožjem mednarodnem (JV-Evropa) ali širšem strateškem okolju bi bila Slovenija kot nečlanica Nata bistveno bolj občutljiva in ranljiva. Z nekaj relativizacije velja enako tudi za vplive, izzive, tveganja in negotovosti, ki jih prinašata proces globalizacije in vključevanje RS v enoten evropski politični in gospodarski prostor.

c) Če Slovenija ne bi postala članica, bi imela manjše možnosti vplivanja, predvsem na politično-varnostne spremembe v ožjem mednarodnem (JV-Evropa) pa tudi v širšem strateškem okolju.

d) Vključevanje RS v EU zaenkrat niti v bližnji prihodnosti ne daje nobenih obrambnih garancij, ker EU nima svojega sistema kolektivne obrambe, niti ni razvidno, da bi sploh imela takšne načrte. Zato članstva RS v EU in Natu z varnostno-obrambnega zornega kota nikakor ne moremo obravnavati kot alternativna, temveč kot izredno komplementarna strateška cilja.

e) Z zavrnitvijo članstva $v$ Natu bi zelo verjetno kmalu prišlo do zmanjševanja občutka varnosti pri slovenskih državljanih. Splošna javnost se pravzaprav ne zaveda, da je pri pojasnjevanju svojega občutka varnosti zadnja leta lahko tako samozavestna prav zato, ker smo v preteklih devetih letih z nenehnim intenziviranjem vključevanja v Nato nezavedno že skoraj postali člani sistema kolektivne obrambe.

f) Brez članstva v Natu bi bila RS v prihodnje bistveno bolj izpostavljena tujim interesom na vseh področjih, najbolj očitni pa bi verjetno bili večja tveganost in ranljivost naložb slovenskih podjetij v Jugovzhodni in Vzhodni Evropi, pa tudi drugje v svetu.

g) Če Slovenija ne bi bila včlanjena v Nato, ne bi imela nikakršnih obrambnih in vojaških zagotovil, vnaprej izkazanih strateških zaveznikov ali prijateljskih držav, ki bi sodelovale pri odvračanju vojaških groženj in bi, če bi bilo treba, podpirale obrambo nacionalne suverenosti države.

Tretji del dokumenta je opredeljeval obrambna tveganja in negotovosti kot posledice zavrnitve članstva:

a) Kljub primerni zunanji politiki, ugodnemu gospodarskemu razvoju in urejenim notranjim odnosom bi morala RS postaviti in ohranjati ustrezen obrambni sistem, ki bi temeljil zgolj na konceptu naslonitve na lastne sile. Oblikovati bi bilo treba celovit in samozadosten sistem totalne obrambe, ki bi zagotavljal odvračanje 
in preprečevanje vojaških konvencionalnh in asimetričnih groženj oziroma obrambo pred njimi.

b) Prilagoditev obrambnega sistema za delovanje zunaj kolektivne obrambe bi zahtevala velike spremembe v strukturi sil, popolnjevanju, modernizaciji, infrastrukturi in obrambnih pripravah celotne družbe.

c) Povečati bi bilo treba mirnodobno sestavo, kar pomeni več poklicnih vojakov in več pripadnikov visoko pripravljene pogodbene rezerve, ponovno bi morali oblikovati ustrezne sile za nadzor in obrambo ozemlja (teritorialna obramba) ter ustaviti opuščanje obvezne (manj pripravljene) rezerve. Za dolgoročno zagotavljanje te številčnejše kadrovske baze bi bilo zelo verjetno treba ponovno uvesti eno izmed različic sistema vojaške obveznosti (selektivno, samoselektivno ali obvezno služenje vojaškega roka).

d) Zagotoviti bi bilo treba pospešeno modernizacijo vseh segmentov obrambnih sil, s posebnim poudarkom na opremljanju celovitega sistema zračne obrambe, zagotavljanju večje količine in kakovosti sredstev za izvajanje bojnega manevra, celovitih sistemov bojne podpore, zdravstvene oskrbe, logistike ter usposabljanja aktivne in rezervne sestave.

e) Začeti bi bilo treba postopno, vendar celovito prilagoditev obrambne infrastrukture ter širšega ozemlja, ki bi ustrezala konceptu totalne obrambe.

f) Za oblikovanje obsežnejših blagovnih rezerv, obsežnejših strateških vojaških rezerv ter celovitejšo in natančnejšo prilagoditev industrije za delovanje ob vojaški ogroženosti bi bile potrebne večje investicije. Ob tem velja poudariti, da bi zaradi ohranjanja koncepta totalne obrambe in z njim povezane sorazmerne množičnosti vojne sestave SV še vedno velik del popolnjevanja obrambnih sil temeljil na sredstvih iz popisa (predvsem vozila).

g) Koncept totalne obrambe bi bil lahko pogojno operativen leta 2008, vendar le pod pogojem, da bi se takoj začela bistveno večja vlaganja od načrtovanih. Poleg tega bi bili brez naslonitve na sistem kolektivne obrambe v naslednjem pet- do desetletnem obdobju izpostavljeni povečanemu varnostnemu tveganju zaradi zmanjšanih zmožnosti za zares učinkovito nacionalno obrambo. Tudi pozneje bi bila obrambna sposobnost RS zaradi obrambne izoliranosti v vse bolj soodvisnem svetu zelo vprašljiva.

h) Izničeni bi bili skoraj desetletna prizadevanja na obrambno-vojaškem področju in dosedanji rezultati intenzivnega prilagajanja SV za delovanje v sistemu kolektivne obrambe. $Z$ eno potezo bi zanikali rezultate intenzivnega izvajanja obrambnih reform $\mathrm{v}$ zadnjih dveh letih, dosedanje dolgoročne obrambno-vojaške razvojne načrte ter vse nacionalnovarnostne in obrambno-vojaške strateške dokumente, iz katerih ti načrti izhajajo.

i) Zavrnitev bi predstavljala zmago protireformistične struje v obrambnem sistemu in še posebej v SV ter bistveno upočasnila proces funkcionalne profesionalizacije.

j) Brez članstva $v$ Natu bi bilo sodelovanje RS v operacijah v podporo miru, ki se jim v prihodnje nikakor ne bo mogoče odreči, veliko bolj omejeno zgolj na drugorazredne naloge, pri njihovem izvajanju pa ne bi bilo mogoče računati na večjo pomoč in sodelovanje članic Nata. 
k) Obrambni sistem, SV, znanstvenoraziskovalna dejavnost in gospodarstvo bi imeli zaradi zavrnitve članstva $v$ Natu bistveno manjše možnosti za aktivno in enakopravnejše sodelovanje v najaktualnejših obrambnih in vojaških razvojnih tokovih, ki jih narekujejo najrazvitejše industrijske države, članice Nata.

Kako so bile leta 2003 opredeljene morebitne opcije zagotavljanja nacionalne obrambe, če podpore vključitvi v Nato ne bi bilo?

V analizi je navedeno, da so poleg članstva Slovenije v Natu še tri teoretične oziroma hipotetične možnosti zagotavljanja nacionalne obrambe, pri čemer nevtralnost ni bila opredeljena kot možnost za zagotavljanje nacionalne obrambe, temveč je to status države. Poleg tega je bila sprejeta ocena, da Slovenija v tedanjih politično-varnostnih razmerah v mednarodni skupnosti, predvsem kratkoročno pa tudi dolgoročno, nima nobenih realnih možnosti za pridobitev statusa nevtralne države in za zagotovitev garancij drugih držav za njegovo spoštovanje. Tako so bile določene možnosti: - strateško dvostransko partnerstvo - glede na trenutne odnose s sosednjimi državami in ob upoštevanju zgodovinskih izkušenj Slovenija predvsem kratkoročno pa tudi dolgoročno nima nobenih stvarnih možnosti za navezavo strateškega dvostranskega partnerstva s katero koli sosednjo državo ali pomembno evropsko silo, ki bi ob doslednem spoštovanju suverenosti Slovenije in njenih nacionalnih interesov imela interes in hkrati možnosti za odvračanje nevarnosti ali sodelovanje pri obrambi RS;

- obrambni segment Evropske unije - unija zaradi obstoja Nata kot sistema kolektivne obrambe kratkoročno ne kaže niti volje niti sposobnosti za postavitev svojega avtonomnega in celovitega sistema kolektivne obrambe; če pa bi se EU zaradi spremenjenih politično-varnostnih razmer v mednarodni skupnosti odločila za svoj sistem kolektivne obrambe, bi njegovo postavljanje trajalo zelo dolgo, končni rezultat pa bi bil zelo negotov;

- samozadosten obrambni sistem - najbolj uresničljiva možnost zagotavljanja nacionalne obrambe zunaj Nata je oblikovanje samostojnega in samozadostnega obrambnega sistema, temelječega na konceptu totalne obrambe, ki bi bil ob poslabšanju politično-varnostnega položaja v regionalnih okvirih vsaj hipotetično sposoben zagotavljati dovolj visoko raven odvračanja nevarnosti in nacionalne obrambe RS, bistveno manj pa v strateških okvirih.

V gradivu je bilo tudi jasno navedeno, da se je bilo treba zavedati, da nobena izmed navedenih možnosti (strateško bilateralno partnerstvo, obrambni segment EU, samozadosten obrambni sistem) ne bi zagotavljala stvarne možnosti za resnično učinkovito odvračanje nevarnosti in obrambo države ob poslabšanju politično-varnostnih razmer v mednarodni skupnosti. Poleg tega je tista možnost, ki bi bila zelo pogojno edina uporabna (samozadosten obrambni sistem), povezana $\mathrm{z}$ izredno velikimi finančnimi in drugimi družbenimi stroški, ki nastanejo z opiranjem na koncept totalne obrambe. 
Ob oblikovanju samozadostnega obrambnega sistema so bile kot pogojno uporabne alternative članstvu Slovenije v Natu izpostavljene nekatere ključne predpostavke za dolgoročno samostojno in učinkovito zagotavljanje nacionalne obrambe, in sicer: - država bi morala takoj začeti gradnjo samozadostnega obrambnega sistema, temelječega na konceptu totalne obrambe, ki bi bil samozadosten in bi že s svojimi mirnodobnimi zmogljivostmi učinkovito izpolnjeval nalogo odvračanja nevarnosti ter dajal ustrezno podlago za oblikovanje potrebnih vojnih zmogljivosti;

- država bi morala v nekaj letih postaviti ustrezno kadrovsko, finančno, materialno in infrastrukturno bazo, ki bi jo bilo mogoče ob zaostritvi politično-varnostnih razmer v mednarodni skupnosti sorazmerno hitro aktivirati ter z njo dopolniti in nadgraditi obstoječe mirnodobne obrambne zmogljivosti. Šele s tako zagotovljenimi vojnimi obrambnimi zmogljivostmi bi lahko zagotovila sorazmerno učinkovito obrambo nacionalnih interesov;

- država in družba bi morali biti pripravljeni vložiti ustrezne finančne in druge vire (ena izmed mogočih oblik vojaške ali državljanske obveznosti, materialna obveznost itn.) v oblikovanje ustreznih mehanizmov za samostojno izvajanje nacionalne obrambe;

- država in družba bi morali biti pripravljeni sprejeti tveganja, s katerimi bi se RS lahko soočila zaradi zavrnitve koncepta kolektivne obrambe in odločitve o gradnji samozadostnega obrambnega sistema.

Strateške možnosti pri oblikovanju sistema samostojnega zagotavljanja nacionalne obrambe so prikazane v tabeli 1 .

Vse strateške možnosti so bile finančno dokaj podrobno ovrednotene, še zlasti z vidika modernizacije, obrambne infrastrukture ter drugih nacionalnih zmogljivosti, v članku pa navajam samo povzetek finančnih posledic za strategijo B. Potrebna bi bila finančna sredstva:

- za oblikovanje novih enot, ponovno uvedbo rezervne sestave in ustreznih oblik služenja vojaškega roka, za zagotavljanje pripravljenosti ter modernizacijo do leta 2008 bi bilo nujno povečanje obrambnih izdatkov za 2,7 do 3 odstotke BDP, kar bi pomenilo letno povečanje za 200 do 300 milijonov dolarjev;

- največje bi bilo povečanje na področju opremljanja in modernizacije obrambnih sil, za kar bi bilo do leta 2008 treba zagotoviti skupaj okrog milijarde dolarjev dodatnih sredstev;

- na kadrovskem področju bi bilo treba do leta 2008 zagotoviti skupaj okrog 200 miljonov dolarjev dodatnih sredstev;

- na področju delovanja, usposabljanja in vzdrževanja obrambnih sil bi bilo treba do leta 2008 zagotoviti približno 230 milijonov dolarjev dodatnih sredstev;

- skupaj bi bilo v obdobju od 2003 do 2008 zaradi nečlanstva v Natu treba namesto predvidenih 2,75 milijarde dolarjev zagotoviti 4,15 milijarde dolarjev, kar je 50 odstotkov več finančnih sredstev.

V sklepu gradiva je bilo poudarjeno, da v tistem trenutku ni bilo nobenih natančno dorečenih in uporabnih konceptov ter načrtov za postavitev in delovanje samostojnega 


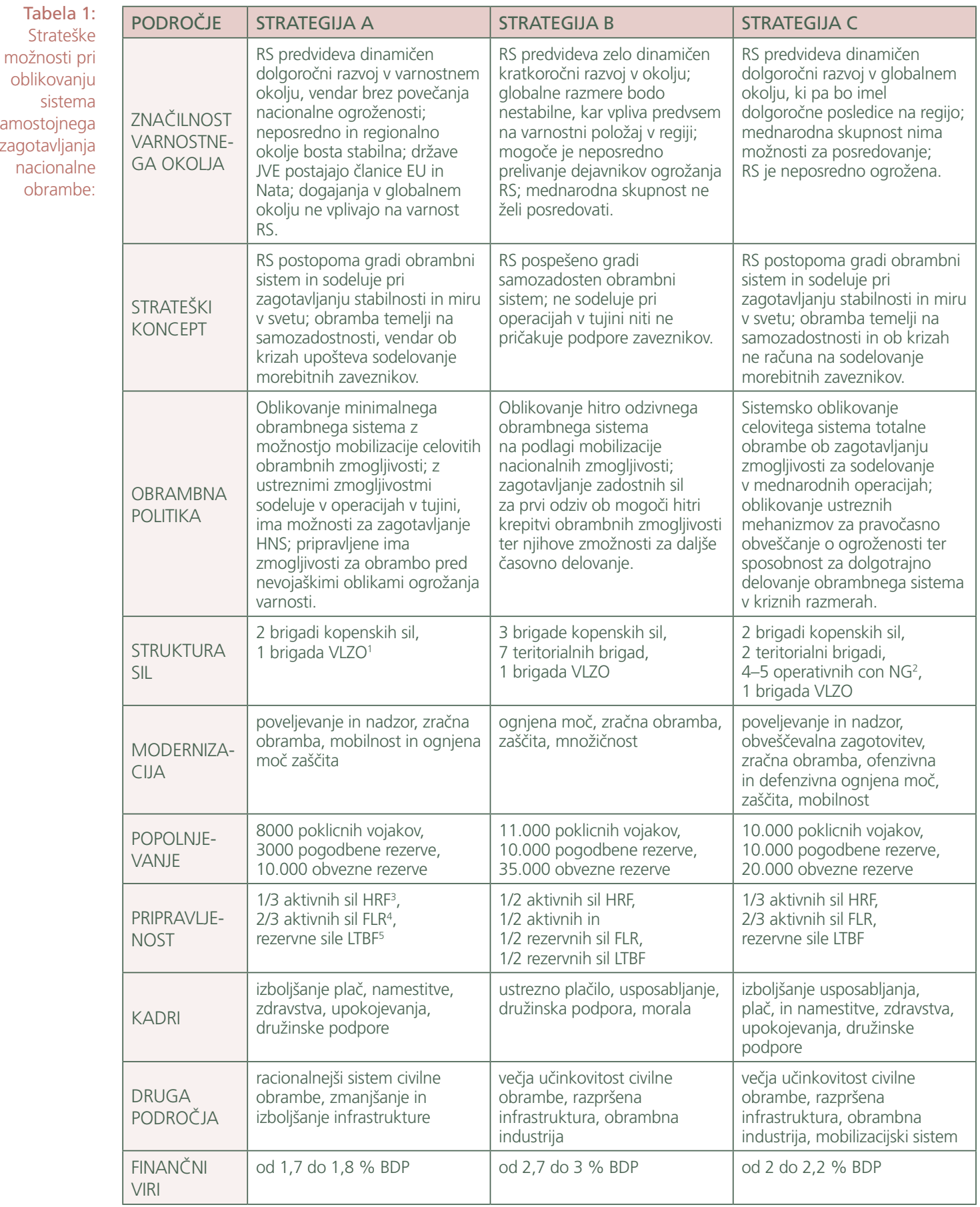

1 Vojaško letalstvo in zračna obramba.

2 Nacionalna garda.

High Readiness Forces - sile za hitro odzivanje.

4 Forces of Low Readiness - sile z manjšo stopnjo pripravljenosti.

Long-term Build-up Forces - sile z daljšim časom vzpostavitve. 
in samozadostnega obrambnega sistema, temelječega na konceptu totalne obrambe. To je bilo tudi povsem razumljivo, saj je bila v zadnjem desetletju odločitev za vključitev v sistem kolektivne obrambe, torej v Nato, stalnica slovenske zunanje politike in poleg članstva $v$ EU prednostni zunanjepolitični cilj. Z zavrnitvijo povabila v Nato bi bili Državni zbor, Vlada in obrambno-vojaška stroka postavljeni pred izredno težke zahteve, da zelo hitro deloma redefinirajo zunanjepolitično strategijo, v celoti pa nacionalnovarnostni in obrambni koncept Slovenije. Pri tem bi nastalo veliko tveganje, da bi ponovno mrzlično iskali najustreznejše rešitve in s tem nacionalno varnost ter druge pomembne nacionalne interese ponovno spravili v negotovost.

Tveganje, da bi Slovenija brez povečanja obrambnih izdatkov in sprememb v predvidenem sistemu popolnjevanja zaradi spremembe obrambnega koncepta $\mathrm{v}$ naslednjem srednjeročnem in deloma tudi dolgoročnem obdobju ostala brez obrambnih zmogljivosti, potrebnih za samostojno učinkovito izvajanje nacionalne obrambe, je bilo izredno veliko.

Povsem jasno je bilo, da je predvideno povečanje obrambnih izdatkov za obrambo do dva odstotka BDP v primeru vključevanja v Nato največ, kar družba lahko prispeva za zagotavljanje ustrezne ravni nacionalne varnosti in obrambe. Nestvarno je bilo torej pričakovati, da bi, če se Slovenija ne bi pridružila Natu, za postavitev kolikor toliko učinkovitega obrambnega sistema namenili do tri odstotke BDP.

To pomeni, da bi zaradi zavrnitve članstva v Natu Slovenija imela v naslednjem srednjeročnem in deloma tudi dolgoročnem obdobju obrambni sistem, ki bi bil popolnjevan, financiran in večinoma opremljen na temelju predpostavke za delovanje $\mathrm{v}$ sistemu kolektivne obrambe, $\mathrm{v}$ resnici pa bi ga želeli brez potrebnih kadrovskih in finančnih sprememb preoblikovati v samostojen in samozadosten obrambni sistem, temelječ na konceptu totalne obrambe, zaradi česar bi bila njegova sposobnost za učinkovito izvajanje nalog nacionalne obrambe zelo vprašljiva.

\section{UČINKI ČLANSTVA V ZAVEZNIŠTVU}

Iz uvodnega dela tega članka izhaja, da je praktično že od začetka obstoja samostojne Slovenija bila odločitev za članstvo v Natu njen strateški cilj (Grizold in Zupančič, 2009) in da je bil ves proces razvoja obrambnega sistema in Slovenske vojske povezan s tem ciljem. Kljub neuspehu v Madridu vsaj v obrambnem sistemu ni prišlo do razmišljanja in celo do priprave drugih možnosti, čeprav je vlada $\mathrm{V}$ kampanji za članstvo jasno opozarjala na posledice zavrnitve. Iz drugega dela članka pa je razvidno, da je bila vlada tik pred referendumom precej negotova o njegovem izidu, zato se je želela neposredno pred njim zelo podrobno seznaniti s posledicami ter možnostmi, če bi volivci članstvo zavrnili. Dejstvo pa je, da smo v zavezništvu že sedem let in zdaj vprašanja, ali je bila odločitev prava ali ne, ne morejo biti več predmet resnih razprav. Seveda pa je sedem let tudi obdobje, ko bi bila zelo primerna celovita analiza učinkov članstva, ki bi ovrednotila uresničevanje ciljev, ki smo si jih na poti v zavezništvo določili, in argumentov, ki so odločitev za zavezništvo 
podpirali, pri čemer pa bi bilo ključno analizirati tudi izpolnitev zahtev želene varnostne drže Slovenije, o kateri piše tudi Bebler (2002, str. 642).

Učinke članstva v zavezništvu sem razdelil v tri sklope: političnega, obrambno-vojaškega in gospodarskega.

Prvi izmed političnih učinkov, ki smo jih definirali v pristopnem obdobju, je bil, da bo Slovenija s članstvom v Natu dobila enakovreden glas pri ključnih odločitvah o evropski in tudi globalni varnosti. To je vsekakor res. Slovenija sodeluje pri vseh razpravah ter sprejemanju vseh stališč in odločitev zavezništva. Dejstvo je, da ima Slovenija enakopraven glas, koliko in kdaj se sliši, pa je odvisno od sposobnosti in ambicij slovenske politike. Enakopravnost glasu seveda ni primerljiva z enakostjo vpliva, ki ga posamezne članice imajo, vendar pa bi se ob odločitvah, pri katerih bi Slovenija imela močan interes, lahko naše stališče bolj slišalo - seveda ob razumevanju vseh tveganj in sprejemanju morebitnih političnih posledic. To je najbolj opazno pri odločanju o operacijah, v katerih zavezništvo sodeluje. Glasu »za« pri pripravah in odločitvi za angažiranje zmogljivosti zavezništva zelo težko sledi glas »proti« pri lastnem vključevanju. Velik politični in javni pritisk je tako slovenska politika doživela ob podpori in sodelovanju v Natovih operacijah v Afganistanu in Iraku, pri Libiji pa se je odločila za politiko podpore brez vojaškega sodelovanja. To je lahko tudi odziv na tisti del kritik, ki članstvo v Natu nujno povezujejo z uresničevanjem interesov ZDA in »bojevanjem za druge«. Drugi izmed političnih učinkov, navajan pri pristopu, je bil tesnejše povezovanje z zahodnimi institucijami in procesi. Vsekakor je temu treba pritrditi. Izkušnje, ki jih je Slovenija pridobila tako pri delu v zavezništvu in njegovih procesih kot tudi pri delu v mednarodnem okolju, z drugimi organizacijami na področju varnosti, z institucijami civilne družbe in političnimi strukturami, so neprecenljive. To velja tudi za izkušnje, načela in vrednote, ki so jih naši sodelavci pridobili pri delu v zavezništvu, za zavezništvo ali z zavezništvom ter z drugimi oblikami mednarodnega sodelovanja. Kljub temu prostor za tesnejše uveljavljanje teh izkušenj doma še obstaja. Tretji politični učinek je izboljšan demokratični (civilni) nadzor nad oboroženimi silami. Na tem področju Slovenija bistvenih težav nima, pridobljene izkušnje so razmere samo še izboljšale, pa vendar posamične oblike in raven oziroma način tega nadzora glede na odnos do obrambe države izhaja iz interesa, ambicij ter načina delovanja zakonodajne in izvršilne oblasti, stroke in tudi javnosti. Torej je članstvo v Natu pripomoglo k razumevanju civilnega nadzora, njegovo uresničevanje pa poteka na nacionalni ravni.

Drugi sklop učinkov članstva je viden na obrambnem in vojaškem področju. Glavni učinek članstva je seveda odvračanje groženj, s čimer se poveča stopnja nacionalne varnosti. Možnost posvetovanja ob sporih, ki lahko privedejo v ogrožanje varnosti, ter zavezanost, odločenost in sposobnost zaveznic za pomoč pri neposrednem ogrožanju ali napadu na državo so značilne samo za Nato. Tako je tudi dolgoročno slovensko varnostno tveganje veliko manjše, kot bi bilo, če ne bi bili člani zavezništva. Seveda na drugi strani to pomeni, da je Slovenija kot zaveznica tudi garant varnosti drugim članicam. Neprimerno bi bilo razmišljanje, ali bi bila v takem 
primeru slovenska politika na veliki preizkušnji. Članstvo v zavezništvu pomeni tudi spodbudo za uresničevanje vojaških reform. Slovenija je bistveno reformo, to je profesionalizacijo vojske, začela že pred polnopravnim članstvom, tako da je vstop v Nato dočakala brez nabornikov. Hkrati s tem sta bila opravljena tudi bistvena reorganizacija oboroženih sil in zmanjšanje s skoraj 70.000 na 14.000 pripadnikov vojne sestave. Kljub optimističnim napovedim o koncu reform je pred nami še dolga pot do celovite profesionalne vojske - od zavezništva smo sicer dobivali jasna priporočila in opozorila, vendar so bile odločitve z vsemi posledicami naše. Pomemben je bil tudi napredek pri doseganju interoperabilnosti z zaveznicami. Pripadniki Slovenske vojske se lahko v strokovnosti, poznavanju procesov in postopkov ter združljivosti opreme in oborožitve enakopravno postavijo ob bok dolgoletnim članicam zavezništva. Izkušnje, pridobljene najprej na skupnih usposabljanjih ter preverjanjih in pozneje v pravih operacijah, so eden bistvenih gradnikov sodobne Slovenske vojske in njenega ugleda med zaveznicami. Nikakor pa ni mogočo spregledati še enega učinka članstva, to je večje vloge pri širitvi regionalne varnosti in stabilnosti. Slovenija je bila med pobudniki ali pa soustanovitelji nekaterih regionalnih pobud, čeprav se zdi, da je naše zanimanje za takšno delovanje upadlo, kar pa ne velja za dvostransko sodelovanje v Jugovzhodni Evropi.

Tretji sklop učinkov je povezan z vprašanji o ekonomskih in gospodarskih posledicah članstva. V pristopnem procesu smo zagovarjali stališče, da se bo s članstvom obseg sredstev, potrebnih za obrambo, dogoročno zmanjšal. To se je v sedmih letih tudi zgodilo, čeprav ne kot posledica načrtnega zmanjševanja zaradi članstva $\mathrm{v}$ zavezništvu, zaradi bistveno izboljšanih projekcij varnostnega položaja države ali zaradi spremenjenega koncepta razvoja obrambnih sil, temveč zaradi pritiskov za zmanjšanje javne porabe kot ukrepa pri reševanju gospodarske krize ter zaradi političnih odločitev pri prednostnem razdeljevanju proračunskih sredstev. Po drugi strani pa je bilo že pred članstvom jasno, da bo kratkoročno nujno povečanje, s katerim bo mogoče zagotoviti ključne elemente interoperabilnosti ter modernizacijo zmogljivosti, povezanih s cilji sil. Pogled nazaj nam pove tudi, da smo premalo naredili na področjih, ki bi omogočila racionalnejšo porabo zagotovljenih finančnih sredstev, kot so na primer združevanje zmogljivosti z zaveznicami in partnerskimi državami, skupni projekti modernizacije, specializacija nalog in s tem usmerjeno opremljanje in usposabljanje. Vsekakor je to odprto polje pri nadaljnji graditvi Slovenske vojske v obdobju varčevanja. V pristopnem obdobju smo kot učinke članstva navajali tudi večjo možnost za pridobivanje tuje finančne pomoči, dostop do občutljive vojaške tehnologije, pripravo okolja za tuje investicije, večjo možnost za vlaganja v raziskave in razvoj ter dostop slovenskega gospodarstva do Natovih projektov. Na tem področju smo učinke precenjevali. Res je, da slovensko gospodarsko okolje zaradi članstva v zavezništvu posredno manj tvega zaradi varnostnega položaja, vendar pa članstvo v Natu samo ni moglo in ne more vplivati na tveganja v gospodarstvu. Dostop do občutljive vojaške tehnologije je mogoč, vendar odvisen od potreb, ambicij in zmožnosti obrambnega sistema. Pri vlaganjih v raziskave in razvoj ter vključevanju v projekte zavezništva je bil dosežen manjši napredek, vendar ostaja dejstvo, da je za obrambno industrijo 
pomemben predvsem domači uporabnik - torej vojska in obrambni sistem, pri čemer pa se začarani krog financiranja modernizacije sklene.

Še en segment učinkov članstva $\mathrm{v}$ zavezništvu je pomemben - to je nov pristop v razmišljanju o obrambi. V pripravah na članstvo se je oblikovala osnovna konceptualna premisa, da bo Slovenija svojo nacionalno obrambo uresničevala znotraj kolektivne obrambe. Ta premisa in jasna politična odločitev za članstvo sta v ozadje potisnili morebitne strokovne kritike, razprave o tem, kaj $\mathrm{v}$ resnici tak koncept pomeni, pa v resnici še ni bilo. Tudi razprave, ki so se odprle o ukinjanju Slovenske vojske, niso bile dovolj konceptualne. Pri kritikih se je pojavljal dvom predvsem o poslanstvu zavezništva in verostojnosti načela kolektivne obrambe ter s tem povezanimi idejami o obuditvi sistema totalne obrambe. Vsekakor je prostor za resno razpravo odprt, ne samo v povezavi s Slovensko vojsko, ki je najpriročnejši objekt za kritike ali polemike, temveč v povezavi s prihodnjo konceptualno in sistemsko ureditvijo obrambnega področja, politično verodostojnostjo ob vprašanju nacionalne obrambe, z uravnoteženim financiranjem obrambnega sistema ter vloge obrambnih sil kot dejavnika slovenske zunanje politike, ne samo obrambne. Potrebujemo trezen in stvaren pogled na to, kakšno nacionalno varnost naj gradimo za prihodnost. Če ne verjamemo $\mathrm{v}$ to, kar smo govorili na poti $\mathrm{v}$ članstvo, če ne verjamemo $\mathrm{v}$ to, kar govorimo zaveznicam danes, če ne verjamemo $\mathrm{v}$ to, kar predstavljamo v naših planskih dokumentih, in če ne zaupamo zavezi kolektivne obrambe, potem je učinek članstva v Natu ničen. Dejstvo pa je, da se spreminja tudi zavezništvo, tako z novim strateškim konceptom kot tudi z razmišljanjem o spremenjeni varnostni paradigmi (Grizold in Zupančič, 2009, str. 213).

Ugotovitve Deset let priprav na članstvo v zavezništvu ter sedem let članstva bi moralo biti dovolj za odgovor na vprašanje, ali smo mislili resno. Reforme, tako preoblikovanje Slovenske vojske v poklicno vojsko, odprava naborništva in obvezne rezerve, bistveno zmanjšanje obsega in strukture ter sprememba zakonodaje, so pokazatelj konceptualnega prilagajanja delovanju v okviru kolektivne obrambe. Obseg angažiranja v mednarodnih operacijah in na misijah ter prevzemanje odgovornih poveljniških in štabnih dolžnosti v vojaški strukturi zavezništva so rezultat naše verodostojnosti in zavzetosti, da smo resna in odgovorna zaveznica ter da smo aktiven dejavnik pri ohranjanju mednarodnega miru in stabilnosti. Vse to kaže, da smo izrabili in uporabili ugodnosti in tudi delili bremena $\mathrm{v}$ zavezništvu, predvsem pa dobili izkušnje o stvarnem obrambnem načrtovanju ter solidarnosti in pomoči med članicami (Bebler, 2009, str.105). Ali smo pred referendumskim odločanjem in med njim imeli na voljo stvarno alternativo? Stvarnost se meri z učinkovitostjo, ali bi torej alternativa izpolnila vse cilje, ki smo si jih glede nacionalne varnosti in obrambe postavili? Drugi dejavnik je sprejemljivost alternative - ali bi torej politika in državljani sprejeli alternativo kot sprejemljivo za dolgoročno zagotavljanje naše varnosti. Tretji dejavnik je dosegljivost alternative, ali smo torej imeli na voljo predvsem ustrezne vire, tako kadrovske kot finančne, ter nacionalno voljo, da bi alternativo lahko uresničili. Alternative iz leta 2003 so sestavni del tega članka, 
odgovor na vse tri dejavnike pa je za avtorja negativen, torej alternative ne bi bile učinkovite, sprejemljive in dosegljive. Ali imamo pred seboj še kakšno možnost? Vsekakor nobene nove, ki bi prenesla preverjanje po treh merilih. Ali imamo alternative razvoja obrambnega sistema in obrambnih sil znotraj članstva $\mathrm{v}$ zavezništvu? Vsekakor da, vendar je za to treba veliko več kot le pogled na obrambno področje, povezan z mandatom ene vlade. Potrebni so jasna vizija, čvrsta strategija, zadostni viri ter sprejemanje tveganj, predvsem pa je treba doseči nacionalni in politični konsenz o tem. Nujno pa je tudi zavedanje, da obrambni sistem in vojska ne moreta biti peskovnik za igre političnih akterjev - na hitro sprejete odločitve, ki so lahko zelo hitro napačne, lahko dolgoročno povzročijo veliko tveganje za nacionalno varnost.

1. Nacionalna strategija Republike Slovenije za vstop v Nato, 1998; Ljubljana, Vlada RS.

2. Akcijski načrt za članstvo; nato.gov.si/slo/dokumenti/akcijski-nacrt, 10. 5. 2011.

3. Resolucija o izhodiščih zasnove nacionalne varnosti, Uradni list RS, 71/1993; Ljubljana, Državni zbor RS.

4. Popravek Resolucije o izhodiščih zasnove nacionalne varnosti, Uradni list RS, 2/1994; Ljubljana, Državni zbor RS.

5. Resolucija o strategiji nacionalne varnosti, Uradni list RS, 56/2001; Ljubljana, Državni zbor.

6. Časovnica obrambnih reform, marec 2003; Ljubljana, Vlada RS.

7. Opcije nečlanstva v zavezništvu, marec 2003; delovno gradivo Uroš Krek.

8. Bebler, A., 2002. Nacionalni interes Republike Slovenije in varnostne sestavine evroatlantskih integracij. Teorija in praksa 4/2002, str. 638-645.

9. Bebler, A., 2009. Pot Slovenije v Nato. Bilten Slovenske vojske 3/2009, str. 105-116.

10. Grizold, A., Zupančič, R., 2009. Pet let v zavezništvu in 60 let zavezništva: Slovenija in Nato. Bilten Slovenske vojske 3/2009, str. 197-216. 